\title{
The rise and fall of project management: are we observing the birth of a new discipline?
}

Michael Young, Raymond Young

University of Canberra

\begin{abstract}
This conceptual paper examines the state of the project, program and project portfolio management literature and highlights the divergent views of strategy that exist between project managers and top managers. Project management concepts are shown to be based on approaches to planning that top managers had rejected after thirty years of unsuccessful experience with strategic planning. Persistently high project failure rates and recent developments at the board level suggest that we might have reached the limits of our current approaches, and the question is asked whether project management is destined to follow the rise and fall of strategic planning.
\end{abstract}

Alternatives to the traditional linear mechanistic approaches are explored and it is suggested that the project management field would need to embrace the delivery of strategy as the common ground to engage top managers. Approaches would need to be developed that are consistent with how strategy emerges in turbulent environments. Program and portfolio concepts are found to have the most potential to contribute to the emerging field of strategy implementation.

Keywords: rethinking project management; new project management approach; top management; project strategy

\section{Introduction}

Strategy is derived from the Greek word strategos. It is an ancient concept first expounded in a military context and refers to a plan of action designed to achieve a particular goal (Ghemawat 2002). Modern corporate strategy was created after the writings of Clausewitz, Sun Tzu and other military strategists were applied to the business domain in the mid-20th century. However, the application has not been consistent and there are different understandings of strategy. In particular, there is a different level of focus between top managers and project managers. The need for research into the overlap between strategy in the management literature and projects to implement strategy has been noted but never fully explored (Okumus 2003).

Modern project management is associated with the World War II Manhattan Project and predates the development of corporate strategy (Kerzner 1998). The use of projects to implement strategy is a much newer development as projects have been traditionally associated with new product development (Artto, et al. 2008). Projects began to be understood as a means to implement strategy and change in the 1970s in the strategic management literature and in the late 1980s in the project management literature (Pelligrenelli \& Bowman 1994; Kwak \& Anbari 2009; Grundy 1998). Further tentative developments in our understanding of strategy in the project management literature occurred with the developments of program management, portfolio management and enterprise-wide approaches to project management (Pelligrinelli et al. 2007; Jamieson \& Morris 2004). 
The strategic management literature does not appear to have had the same developments. The strategic management literature differentiates strategy formulation from strategy implementation (Fiegener 1990), with strategy formulation being the dominant theme. Currently, there are no practical or theoretically sound models for strategy implementation (Alexander 1991; Okumus 2003). There have been many calls for further research on the implementation of strategy, but so far they have gone largely unheeded (Alexander 1991; Pinto, Clelend \& Slevin 2003; Bossidy \& Charan 2002).

A seminal 1994 publication may explain why research into strategy implementation has not made much progress. The article was titled 'The rise and fall of strategic planning' (Mintzberg 1994) and described the failure of strategic planning to produce the expected results despite decades of intensive effort. With the decline of strategic planning, strategic planning teams and 3-5 year long-range strategic plans, strategy thinkers had to focus on finding and developing new approaches to strategy formulation such as Porter's five forces model, generic strategies, the resource-based view of the firm and dynamic capabilities. Mintzberg and Waters (1985) suggested that disruptive change had rendered ineffective the analysis of past trends as a technique to predict and plan for the future. As a result, firms have steered away from deliberate and planned approaches, and relied instead on patterns of strategy to emerge over time.

Over this same period, the influence of project management has grown and continues to be widely adopted throughout the world. The membership of project management associations and professional bodies in various countries is reported to be growing at 40,000 per annum (PMI website) and some predict the demand for project management professionals will continue to outstrip supply (Young, 2008). The divergent trends are disturbing.

Project management and strategic planning share similar origins and use similar concepts and techniques to conceive and control implementation outcomes. The mechanistic concepts that underpin strategic planning also underpin project management, program management and portfolio management (Lycett, Rassau \& Danson 2004). These concepts no longer have much credibility with senior management, yet project, program and portfolio management depend on senior management support for success (Young \& Jordan, 2010; Young, et al.; Pinto, Clelend \& Slevin 2003). This suggests that the current approaches to project, program and portfolio management may have a problematic future and perhaps are destined for failure. This conclusion is independently supported by a seminal article in the management field, which suggests that we have reached the limits of the planning approach (Rittel \& Webber 1973).

This conceptual paper has two aims. It will consider whether project management is destined to follow the decline of strategic planning and whether there are alternatives to the traditional linear and mechanistic approaches to strategy formulation. In considering this question, this paper will also seek to bridge the project management and strategic management literatures.

The sections to follow will first review the understanding of strategy in the project, program and portfolio literature. Then the top management understanding of strategy will be reviewed in detail to provide a basis to evaluate the performance of projects in delivering strategy. Finally the discourse will be critically reviewed to assess whether we have reached the limits of our current project management approaches and whether new approaches need to be developed. Developments in the strategy literature will be examined for insight into possible approaches to develop project management practice. 
We start by examining the concepts underpinning project management and the project management understanding of strategy.

\section{Project-based planning}

Project management thinking is dominated by the rational deterministic model of management, which emphasises planning and control (Van Donk \& Molloy 2007). Project management tools and techniques tend to be mechanistic and linear and based on industrial revolution or scientific management concepts. The theoretical underpinnings were developed by Taylor, Fayol, Gantt and their contemporaries (Morris 1994) who proposed order and structure as the best means of control, based on the assumption that there was 'one best way' to do each job (Whitty \& Schulz 2007).

Structured, linear planning approaches gave project managers a way to limit uncertainty and deliver project outputs on time and on budget. These approaches include the requirement for clear, unchanging and well considered project strategy, hierarchical project team structures, detailed plans, accurate time and cost estimates and strict control methods. At the strategic level, this approach required hierarchical links between individual projects and a documented and articulated strategic plan. The desired result is a 'cascade down' from strategy to programs and projects (Ansoff 1965). The prerequisite for this approach to work is a clearly defined and articulated strategy in terms of strategic objectives, targets and measures (OGC 2009).

The rational planning logic applied to the many projects being undertaken in an organisation has informed the mainstream practices of program and project portfolio management (PPM).

\section{Project portfolio management}

A project portfolio is defined by the leading project management organisations as ' ... a collection of projects or programs and other work that are grouped together to ... manage and control ... risks, resources and priorities ... [and] meet strategic business needs' (PMI 2008), 'achieve strategic objectives' (OGC 2009) or 'manage a common and shared pool of scarce resources' (IPMA 2008). Industry guidelines allow the portfolio to be implemented in part of an organisation such as a division or enterprise-wide. However implemented, the key rationale for portfolio management is for organisations to make rational investment decisions that result in the delivery of organisational benefits in an effective and efficient manner (Dye \& Pennypacker 2000) and the attainment of strategic goals (Foti 2002).

The theoretical underpinnings of PPM were developed in the financial sector (Markowitz 1952) and then heavily influenced by the new product development discipline (Cooper, Edgett \& Kleinschmidt 1999). Modern Portfolio Theory proposed that rational investors should use diversification to optimise their financial portfolios (a collection of financial assets and investments) to achieve higher returns with reduced risk. However, diversification, while broadly applicable to projects, did not necessarily take into account resource constraints and interactions between projects across an organisation. McFarlan (1981) tried to address these issues when he applied portfolio management concepts to information technology (IT) projects. He suggested that the collective management of unrelated projects could optimise an organisation's desired business outcome while minimising the overall level of risk. McFarlan added that desired business outcomes should not be understood as static goals, but as goals that changed over time as a result of shifts in the various legislative, political, economic, social and technological drivers. 
The practice of project portfolio management has focused on selecting the right projects (Archer \& Ghasemzadeh 1999; Jamieson \& Morris 2004) by assessing and balancing risk and strategic fit (Cleland \& Ireland 2007). The focus is on achieving what is needed, rather than just doing one's best (Miller 2002) and the portfolio approach puts the focus on the question of what is strategically important to an organisation (Foti 2002). The OGC expand this to claim that the focus should be on a portfolio of organisational change (OGC 2009).

Some have questioned whether current portfolio management practices are meeting the intended goals or needs of a modern project-based organisation. Krebs (2009) suggests that current portfolio management tools and techniques are not enabling organisations to effectively deal with the emergent and dynamic nature in which projects are identified, commenced, managed and cancelled. The PMI (2008) and OGC (2009) portfolio management frameworks imply that dynamism occurs through portfolio balancing, yet they depend upon rational, mechanistic and linear processes to determine, on a quarterly or annual budget cycle, a project's alignment or 'fit' with an organisation's strategy and priorities. Like planning at the project level, portfolio management assumes that there is a strategy that is understood and that it is stable enough over the planning time frame because the operating environment is stable.

The assumption of stability underpinning portfolio management practices is unlikely to be valid. The modern business environment is turbulent and has been rocked by unpredictable forces such as deregulation, globalisation, technological discontinuities and environmental concerns (Prahalad \& Hamel 1994; Emery \& Trist 1963). Customer tastes change more rapidly than the quarterly or annual planning cycles, as do the demands of other key stakeholders such as investors and suppliers. Most recently, the effects of the ageing population have introduced another seismic issue related to staff and skill shortages. The relatively stable and static world that preceded the industrial revolution no longer exists. These considerations suggest that the environment in which the optimal portfolio operates is not static, but ever-changing because the strategies and priorities of an organisation need to react to the market and external environmental shocks. The rational, mechanistic underpinnings of portfolio management may therefore be unsuited to meet these demands.

\section{Program management}

In contrast, program management is meant to adapt to change and be a tool for strategy implementation (Artto et al. 2008). Its main strength is the recognition that programs, rather than individual projects are generally needed to realise strategic goals. In theory, projects can be added to or dropped from a program as required to respond to changes. However, program management is far from being a mature discipline (Stretton 1992).

The literature is sparse with very few published texts (Williams \& Parr 2004; PMI 2008; Reiss et al. 2006; Milosevic, Martinelli \& Wadell 2007; OGC 2007; Thiry 2010) and only one with a strategic orientation (Pelligrinelli 2008). Curiously, all these texts start by commenting on the dearth of available guidance. Milosevic et al. (2007) explain that program management originated in the United States aerospace and defence industries where it was kept secret for decades. They add that it was only in the 1980s that program management took hold in the commercial sector and even then it was sometimes just the term being misapplied by project managers to the management of large or multiple projects.

The strategic orientation of program management is seen in the leading methodology, Managing Successful Programmes, which focuses on the delivery of change (OGC 2007). 
The only other well-known methodology, Standard for Program Management, is more project-oriented and focuses on new product development (PMI 2006).

Some have argued that these mainstream program management methodologies are too strongly influenced by the rational project management tradition because practices have been codified too rigidly (Lycett, Rassau \& Danson 2004). Pellegrinelli et al. (1997) find that the required level of documentation works against the need to challenge and redefine the program as new information comes to hand. They believe that current guidelines understate the need to adapt to the strategic context and ensure the strategic benefits are actually realised. The mainstream approaches are focused on a narrowly defined program and assign responsibility for the realisation of benefits to business managers at the boundaries of the program (OGC 2009). Pellegrinelli et al. (2007) conclude that the current codification into a common set of transferable principles and processes is inadequate and report that practitioners have found many of the guidelines are either not useful or do not make sense.

\section{The project management understanding of strategy}

Given the shared origins of project management and strategy, there have been attempts to merge the two disciplines. In the project management literature, this has resulted in the development of the concepts of project alignment and project strategy.

\section{Alignment}

The project management literature implies that projects are undertaken to meet organisational goals (Cooke-Davies, Crawford \& Lechler 2009) at the corporate, business-unit or functional levels (Srivannaboon \& Milosevic 2006) and that projects should be linked, aligned to or 'fit' an organisation's strategy (Cleland 2004; Archer \& Ghasemzadeh 2004; Dietrich \& Lehtonen 2005; Milosevic \& Srivannaboon 2006). This bottom-up focus on the alignment between projects and strategy is strongly influenced by the work of Ansoff (1965).

The concept of alignment is also applied to project portfolios. When projects and programs are added to a project portfolio, strategic 'fit' or alignment to the organisation's strategy is recommended as a key selection criterion (Archer \& Ghasemzadeh 1999; Archer \& Ghasemzadeh 2004; Cleland 2004; Dietrich \& Lehtonen 2005; Dinsmore \& Cooke-Davies 2006; Cooper, Edgett \& Kleinschmidt 1999; Kaplan \& Norton 2008).

However, despite the heavy emphasis of alignment in the literature, there do not appear to be any empirical studies of alignment. We have no idea of the degree to which projects can be aligned to strategy and there appear not to be any examples of how alignment has been achieved in practice.

\section{Project strategy}

The literature also has another related concept: project strategy. Project strategy mirrors the bottom-up concept of alignment. Project strategy is the direction or approach taken in a project to ensure it makes the greatest contribution to success in its environment (Artto et al 2008). Project strategy relates to the way the project team sets about achieving a project's objectives and goals (Dinsmore \& Cooke-Davies 2006). The concept appears to have been developed as a conceptual bridge that links corporate and business unit strategy to the delivery of projects (Morris \& Jamieson 2005). Project strategy is typically developed at the start of a project to agree on project goals and to provide guidelines to execute the project work (Artto et al. 2008). 
Many authors have developed the concept of project strategy (eg Dinsmore, Cooke-Davis, Morris, 2006) but like alignment, there are very few empirical studies of the phenomenon. There has been little or no research on the influence of project strategy on organisational strategies (Thiry \& Deguire 2006). Artto et al (2008) reviewed the project strategy discourse and found that project strategy was not always subservient to a parent organisation's strategy and sometimes operated autonomously.

Artto et al (2008) concluded that the literature in the project strategy field is far too narrow with an almost singular focus on planning. There is an assumption that projects can be aligned to an organisation's strategy or organised to maximise realisation of strategic goals. However, one must ask if either aim can be achieved if formal, documented strategic plans do not exist. If strategy is not formulated in the rational manner assumed by the project literature and if the organisation strategy changes or evolves, how is alignment maintained or how is the project strategy kept relevant?

Before we explore such questions, it is important to examine strategy from the top management's perspective and see how it differs from that of the project management community.

\section{Top management's understanding of strategy}

Strategy has become an all-purpose term applied to a range of management techniques, theories, concepts and corporate issues, and subject to fads and fashion (Choo 2005). It is a term used to describe lofty, important or wide-ranging concepts (Mintzberg 1993) and is also considered analogous to terms such as guiding motives, matching of the internal and external environments or series of actions (Chaffe 1985). From the top management's perspective Wright et al.'s (1992) definition seems appropriate '... top management's plans to attain outcomes consistent with the organisation's missions and goals'.

Strategy can operate at the corporate, business unit and functional levels of an organisation (Srivannaboon \& Milosevic 2006; Porter 1996). Corporate strategy is concerned with enterprise-wide decisions in diversified organisations and relates to which industry sector and markets to compete in (Hofer \& Schendel 1978). Corporate strategy deals with growth (through acquisitions, new ventures or organically) and divestments, diversification or retrenchment (Porter 1980). Corporate strategy is often represented as the portfolio of businesses for investment and formalised as a corporate strategy document to coordinate effort at the business unit level (Porter 1980). Business unit strategy focuses on how a firm competes within a particular industry or market and is concerned with how to achieve a competitive advantage over rivals. At the functional level, strategies focus on short- and medium-term plans within each functional department to ensure they contribute to the overall corporate objectives. These include strategies for marketing, new product development, human resources, finance, legal, supply chain or IT. Project portfolios can be created at this level by consolidating functional strategies and managing them collectively.

There is no recognised 'one best way' of developing strategies or strategising. Authors such as Karlof (1987), Nasi (1995), Gilbert et al. (1988) and Elfring and Vorberda (1994) each suggest different 'schools of strategy'. The most popular categorisation, with over 3200 citations, is that of Mintzberg et al. (2005), who suggest that there are 10 schools of strategy. These schools range from traditional strategic planning, positioning and resource-based views to the more recent political, cultural, cognitive and environmental schools adapted from concepts in politics, biology, sociology and psychology. Figure 1 shows the schools 
schematically.

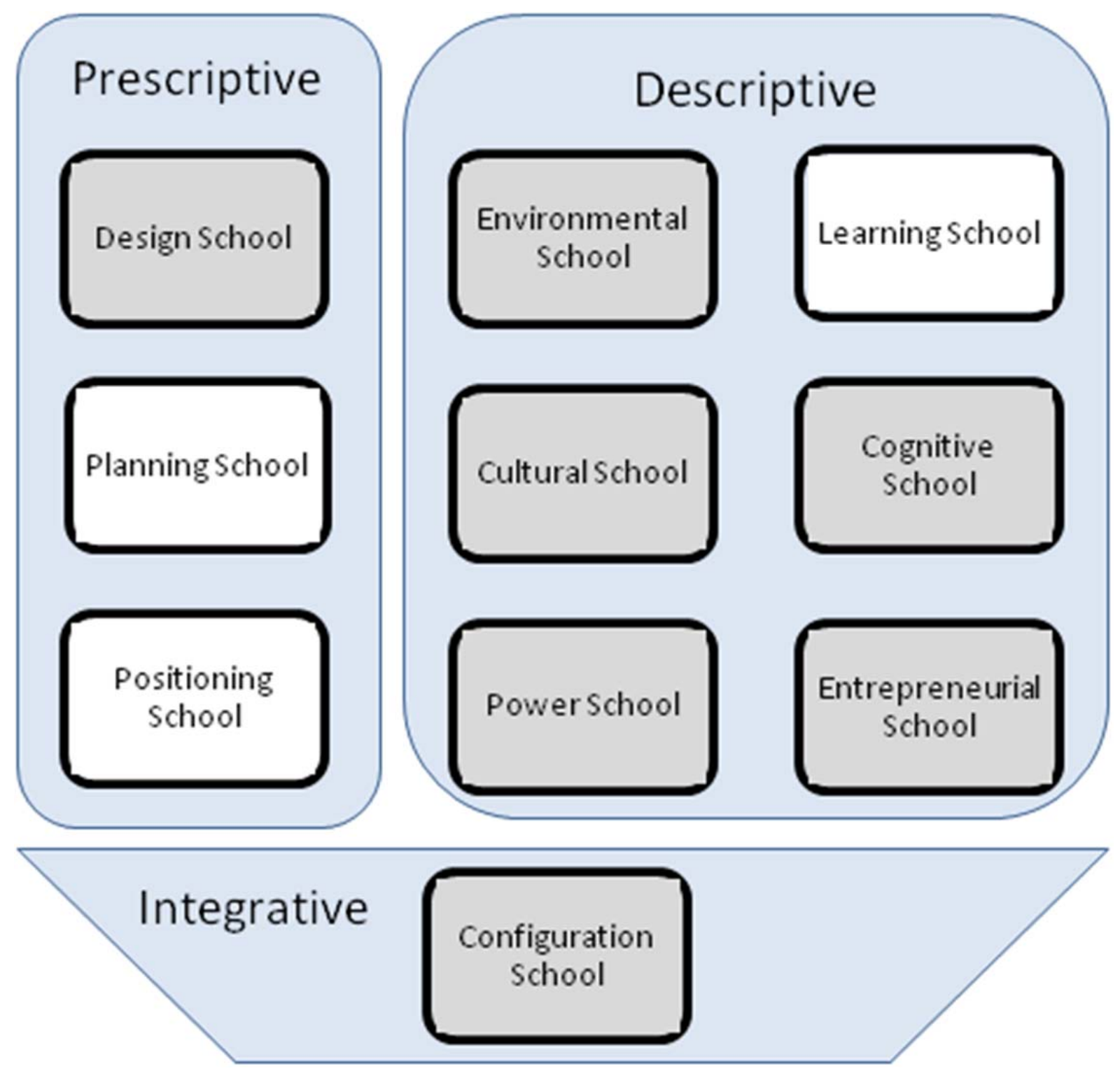

Figure 1. Mintzberg's schools of strategy

Three of these schools, the planning, learning and positioning schools, have at various times dominated strategic thought (Mintzberg 1994) and have very close associations with the disciplines of project, program and portfolio management. In this paper we will limit ourselves to examining these three perspectives.

\section{Planning school}

The planning school is a prescriptive view of strategy and represents the first and most influential school. It is focused on the process of formulating a strategy rather than the content of the strategy itself. Planning is forward-looking and requires clear articulation of intentions supported by formal controls to ensure plans are consistently pursued in an everchanging environment (Mintzberg \& Waters 1985). It is typified by Ansoff's Model of Strategic Planning where a series of plans are developed at the corporate, business unit and at functional level of an organisation and builds on the concepts proposed by Taylor, Fayol, the Gilbreth's and Gantt. Typically, strategic plans were developed for the medium- to long term, 
covering a period of three to five years. Figure 2 shows an example where a strategic plan is cascaded down to operations and projects with alignment between strategy and projects

(Stewart 1963).

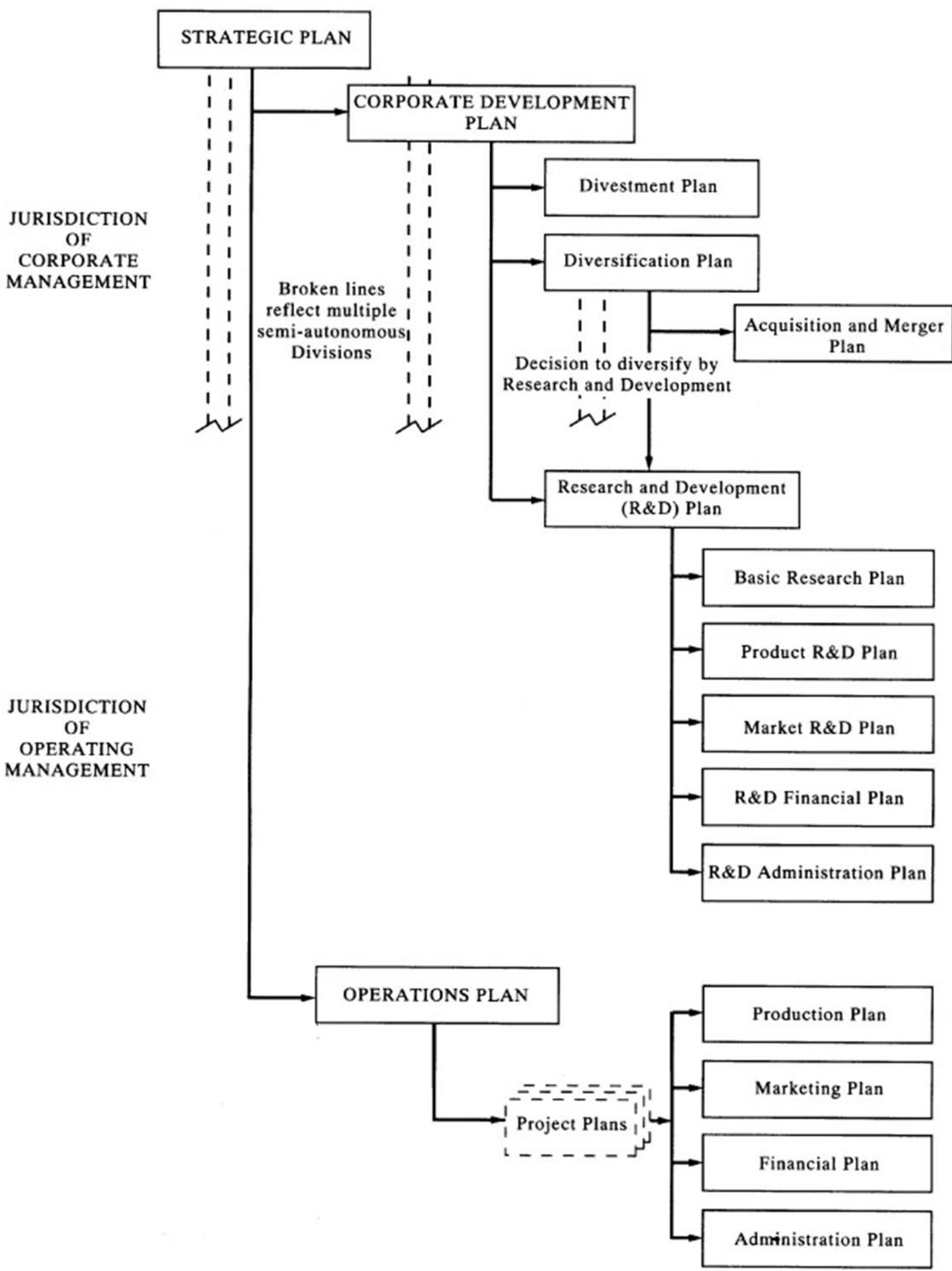

Figure 2. Systems of plans. Source: Mintzberg (1994)

The process of strategic planning starts with a plan formulated by the planning staff and approved by top management. The plans are then decomposed so that lower-level tasks can 
be scheduled and allocated to specialised areas of the organisation. The strategy is then implemented by operational staff, often in complete isolation from those who formulated or approved the strategy. This approach to strategic planning closely parallels the mainstream project management planning process.

The strategic planning school, however, began to lose favour in the 1980s (Mintzberg, Ahlstrand, \& Lampel 2005). The regimented strategic planning process failed to develop any true strategic choices and produced virtually no results (Wilson 1994). Formal plans that were produced either decayed or required constant adjustment during periods of turbulent environmental change: some changes occurring so rapidly that the organisation focused all its efforts on constantly replanning, with strategy implementation never actually occurring (Wilson 1994).

The key reason for the demise of the planning school was the misguided assumption that a formal plan could provide long-term guidance (Wilson 1994). Planners did not entertain the possibility that the environment could not be predicted with any great accuracy (Mintzberg \& Waters 1985) and that the plan would be of no use because it could either not be implemented or would not be useful even if it were implemented. With rapid change, the process had to be simplified and well thought out strategic plans became nothing more than an extrapolation of existing patterns or were copied from standard industry recipes (Grinyer \& Spender 1979). In addition to this, after plans were developed and championed, changes to plans were resisted by top managers in an attempt to save face (Mintzberg \& Waters 1985). This dysfunctional behaviour accelerated the downward spiral of planning.

With the demise of large formal strategic planning in almost all organisations over 30 years ago (Lorange 1998), doubts have flowed through to the project management literature with some authors questioning the merits of formal project planning (Anderson 1996; Bart 1993).

\section{Positioning school}

The positioning school that followed was also a prescriptive approach to strategy. It is characterised by two key themes: portfolios and Porter's market-based concepts. In the positioning school, strategies are desirable and defended positions in the economic marketplace. This reflects the military strategy from which the concepts of positioning originated (Mintzberg, Ahlstrand \& Lampel 2005).

The positioning schools started with a number of portfolio-based models developed mainly by consulting firms such as Boston Consulting Group (BCG). The BCG Growth-Share Matrix is based on the expected ability of an organisation to take a cost-leadership position based on experience (production volume). The BCG growth-share matrix was a product portfolio planning approach and drew on the earlier concepts of Markowitz and Modern Portfolio Theory. The approach was to analyse the different growth rates of products and the potential market share that could be gained to evaluate whether a cost-leadership position could be achieved. Products were classified as stars, cash cows, question marks or dogs. The analysis guided organisations to allocate most funds to developing their stars, maintaining investment in their cash cows, allocating some venture capital to the question marks and divesting themselves of their dogs (Mintzberg, Ahlstrand \& Lampel 2005; Henderson 1979).

Cost leadership as the main strategy was challenged by the example of Japanese manufacturing in the American motor industry. It became clear that the experience curves were not the same in all industries and some profitable positions were hard to maintain in the face of competition. In addition, some of the positions that were identified and recommended 
were found to be impractical because organisations are limited in their resources and often could not transform themselves enough to develop the strengths needed to take a desired position in the market (Keichell 2010).

The positioning school responded to these limitations with Porter's publication of Competitive Strategy. Drawing on economic theories, Porter (1980) shifted the strategic focus to an external industry-based view. He argued that the fundamental basis for long-run aboveaverage performance is not based on position alone but on a sustainable competitive advantage. Without a sustainable advantage, an organisation could not continue to make the largest possible profits over the long run. Porter (1985) proposed three basic strategies for pursuing competitive advantage: cost leadership, differentiation and focus.

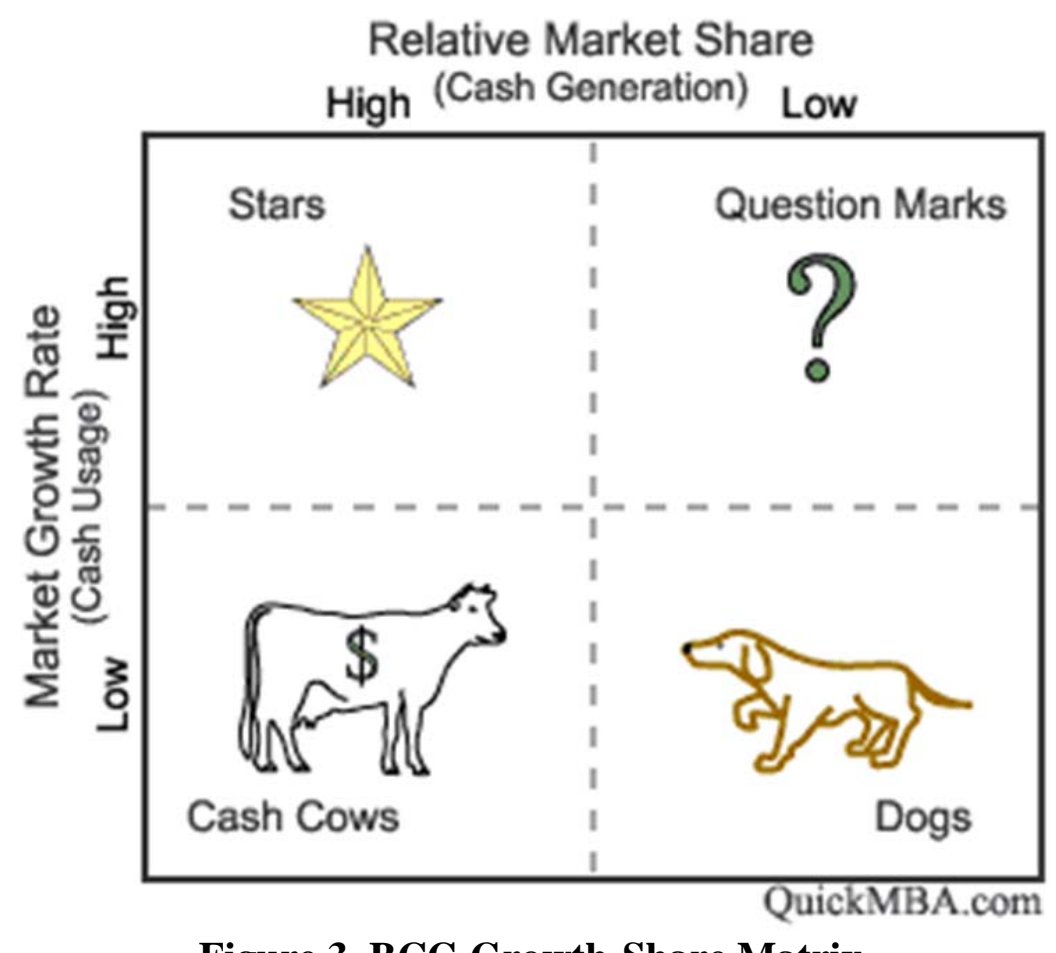

Figure 3. BCG Growth-Share Matrix

Under a cost leadership strategy the firm sets out to become the lowest cost producer in its particular industry. The principles had been established that to be a cost leader the company had to become a high volume producer to leverage the learning curve and exploit every source of potential cost advantage.

Following a differentiation strategy, a firm seeks to be the best performer in its industry grouping along at least one dimension other than cost, such as product quality or level of customer service. This dimension must be something that customers perceive as important, and so the company positions itself uniquely to meet those needs with the result being premium prices and higher profits.

The focus strategy is not based on the selection of desirable attributes for a product or service across the whole of an industry grouping but upon the needs of a particular customer segment or group. The company focuses on the needs of a niche market. Having identified a niche, the company needs to tailor its strategy specifically to serve the needs of that particular group. The focuser seeks competitive advantage in its own segment. To be successful, it must exploit the underperformance of its more broadly based competitors in that niche, based either on cost or differentiation. 
The positioning school has been criticised because of its focus on analysis rather than the process of strategy formulation or the strategies themselves (Mintzberg, Ahlstrand \& Lampel 2005). The positioning school eventually suffered the same fate as the planning school when the environment became turbulent. The core concepts were based on the assumption of environmental stability, but the ability to predict future industry and competitor behaviour turned out to be far more difficult than anticipated partly because of so-called irrational decision making (Coyne \& Subramaniam 1996). What was needed was an approach that dealt with the dynamic nature of the environment that allowed the organisation to continuously learn and improve.

\section{Learning school}

The learning school of strategy does not base strategic formulation on planning or analysis, but on strategists and organisations learning over time through interpretation and reflection on past experiences (Mintzberg 1994; Balogun 2006; Sull 2005; Carlopio 2006; Weick 1995). Instead of strategies being deliberately formulated as a one-off decision, they are formed incrementally. Strategies were seen to emerge and be refined as the top management responded to events in the environment. An advantage of this approach was seen to be the creation of an evolving new, widely shared consensus for action (Quinn 1978). Emergent strategies open up the notion of strategic learning, with managers working out what works and what doesn't on an incremental basis, and taking specific actions based on those specific learnings. Weick (1995) explains 'all understanding originates in reflection and looking backward'.

However, adopting an emergent strategy does not mean operating in a chaotic state without control, operating without a strategy or 'making things up as you go'. Instead, it is based on the concept of unintended order and requires an organisation to be flexible, responsive and willing to learn. This is of particular importance in highly dynamic environments. Managing emergent strategies is not to preconceive, but to recognise emergence and intervene when appropriate (Mintzberg \& Waters 1985). As such, an organisation may recognise the merits of past patterns of behaviour and formalise these for the future through a more deliberate strategy.

The learning school of strategy may be consistent with concepts of program management. Quinn's (1978) theory of logical incrementalism and Senge's (1990) learning organisation are particularly similar although program management is probably more structured and deterministic.

\section{Critical assessment of current project management discourse}

While there has been significant developments and empirical research conducted in the discipline of project, program and portfolio management, there are still significant shortcomings.

\section{Need for top management support of projects}

The fact that intensive effort over the past 50 years has not significantly improved project success rates (however defined) strongly suggests the current approaches are not working and that new ones are needed (Author, et al. 2012). Research to identify the most promising new direction(s) to overcome the problem of IT project failure was conducted with Standards Australia and 170 other organisations from 2002 to 2006 (HB280 2006). This research identified top management support as a more important factor for project success than the traditional emphasis on project methodologies, user involvement, high-level planning or 
project staff (Author \& Jordan 2008). The research informed what became ISO38500, the new international standard on the governance of IT, and AS8016-2010, a standard for the corporate governance of projects.

The new project governance guidelines understood that even if top management support is essential for project success, it is impractical to require boards and top managers to spend more than a portion of their time on projects. Mechanisms and processes are needed to ensure top managers intercede in projects at the right moments. There is no consensus on the best mechanisms and process to involve top managers, but the most promising developments appear to be in the area of project governance supported by tools such as portfolio and program management.

In some ways, this new development is uncontroversial because top management support has long been recognised as being important for project success (Lederer \& Mendelow 1988; Pinto, Clelend \& Slevin 2003; Garrity 1963; Rockart \& Crescenzi 1984). However, the implications are very significant because if boards and top managers have the most influence on project success, the current advice is probably misdirecting effort. Projects are rarely considered to be a matter of direct concern for top managers (Crawford 2004), and a significant change in behaviour will be required by top managers and their advisers for projects to consistently succeed (Young \& Jordan, 2008). How can top managers support projects if there are divergent views of strategy and differences in perspectives on the importance of planning?

\section{Reliance on outdated long-range planning concepts}

A key shortcoming in the concept of strategy in the project management literature (alignment and project strategy) is a myopic view of strategy that does not correspond to top management perspective of strategy. One of the inherent assumptions in the project management literature is that an organisation has a pre-existing holistic and well-documented strategic plan that is referenced in decision making and actively used to determine organisational priorities. The expectation of a strategic plan, formulated in a linear, mechanistic and rational manner, is that it remains relevant and relatively stable over the medium term (3-5 years). These long-range planning concepts are at odds with the current thinking on strategy, do not recognise that strategy may be emergent (Mintzberg \& Waters 1985) and do not recognise other schools of strategic thought.

There is also the assumption that the long-range planning approach is a best practice. Top managers have long since moved on to try other approaches to strategy and it is a concept that has been discounted by contingency theory, which states that there is ' ... no universal or one best way to manage'. Long-range forecasting (two years or longer) has also been found to be notoriously inaccurate (Hogarth \& Makridakis 1981).

\section{Isolation of project management literature}

The project management literature is isolated from the mainstream management disciplines (Thiry \& Deguire 2006). This is apparent in both the strategic management literature, where the concept of using projects as vehicles to implement or execute strategy is lacking, and in the project management literature where strategic management concepts are limited to alignment of projects to organisational strategies. Thiry and Deguire (2006) suggest that very few project management papers are exported to the general management audience, with the majority of project management papers being confined to the Project Management Journal and the International Journal of Project Management. 
In addition, project managers do not see themselves as 'managers'; nor do they actively take part in general management communities (Thiry \& Deguire 2006). Outside the project management discipline, as an organisational concept, project management is relatively new, not well understood and understudied (Shenhar \& Dvir 2004). For the most part, the project management literature treats projects as a subset or branch of organisations at best, and at worst, a concept utterly disconnected from organisations.

A major new initiative called 'The Rethinking Project Management Research Agenda' has considered this situation. Their conclusion is that traditional project management research has been fundamentally limited to improving tools and techniques for single projects (Winter et al. 2006). Five new research directions were proposed for the project management field:

(1) to recognise the complexity of projects and encourage more models and theories to manage different types of projects

(2) to recognise the social nature of projects and encourage human interactions, multiple stakeholders and power relations to be considered in research

(3) to shift the focus to value creation and pay more attention to emergence, sense making and multiple expectations/meanings (Winter 2006; Sauer \& Reich 2009)

(4) to build broader conceptualisations of projects and acknowledge the multidisciplinary, emergent and negotiable concepts and approaches that can be pursued

(5) to move the conception of practitioners from trained technicians to that of becoming reflective practitioners who can learn, adapt and apply theory effectively in their practice domains.

However, when changing the unit of study from individual projects to programs, portfolios or wider organisational and strategic management contexts, the literature on how to manage such a collection of projects is relatively sparse, divergent and poorly integrated (Young, Owen, \& Connor, 2010).

\section{Lack of appreciation of strategic management literature}

Some concepts from some strategic management schools have been incorporated into the project management literature, but these seem not to be well understood. Cooke-Davies et al. (2009) and Srivannaboon and Milosevic (2006) adopt only Porter's positioning-based view of strategy, and use Porter's generic strategies to determine how projects should align to the organisation's strategies. Other authors, such as Morris and Jamieson (2004) and Milosevic and Srivannaboon (2006), acknowledge that strategy can emerge over time, but still expect a linear relationship between strategy and projects where corporate objectives cascade down through portfolios into programs and projects. There has been little or no focus on examining projects in the context of other 'schools' of strategy as Winter et al. (2006) recommend.

Project management ignorance of top management understanding of strategy may be a serious shortcoming. It is widely accepted that top managers are needed for projects to succeed, yet project management concepts are framed mostly in terms that the top management community have tried and rejected. In particular, the rational deterministic planning process underpinning all project management thought has been discarded by top managers after many decades of unsuccessful effort (Mintzberg 1994). Failure is all but inevitable and traditional project management may be destined to follow the course of strategic planning. There are worldwide demands for higher standards of corporate governance and responses at the board level suggest projects will come under closer scrutiny (AS8016 2010; Author \& Jordan 2010). One suspects management will cry enough is enough sooner rather than later in this new environment. 
At the project level, project managers have failed to get top management to support effort to deliver outputs on-time and on-budget because it is not an issue considered to be of direct interest to top managers (Crawford 2004). Strategy is of direct interest to top managers but unless project managers share similar conceptions of strategy, it surely is only a matter of time before their attempts to engage top managers through project portfolio techniques will also fail. Top managers are not primarily focused on efficient resource utilisation. They are interested in strategy and their conception of strategy has moved well beyond the planning school. It seems foolish to persist with approaches that top managers have rejected or to remain focused on issues they do not consider to be of direct concern.

\section{Do portfolios really deal with strategy?}

While much of the literature suggests that PPM is the link between an organisation's strategy and its projects, is this really the case? If the link between strategy and projects that exist in the portfolio is nothing more than some form of 'alignment', it is unclear how a project portfolio would help an organisation achieve strategic outcomes, particular in an increasingly dynamic environment where strategy is emergent, or there is no documented and promulgated strategic plan.

The justification for PPM is not convincing when applied to the implementation of strategies not related to new products. Questions have been raised on whether PPM actually adds any value at all. One study reports that fewer than 33\% of organisations using PPM use it to diversify and reduce portfolio risk (De Reyck et al 2005). Thiry and Deguire (2006) find that PPM, because it is meant to deal with fairly stable environments, can only be effective if combined with program management that is meant to deal with more turbulent environments and emergent strategies. They add that PPM project selection and risk management practices are not complementary to top managers' strategic non-linear decision-making processes.

\section{Lack of appreciation of the increasingly dynamic environment}

Dynamism and emergence are challenging concepts to the linear, rational and mechanistic planning school, because this school is best suited to operate large mechanistic bureaucracies in a simple, stable, predictable and controllable context (Mintzberg 1994), in line with Burns and Stalker’s (1961) Structural Contingency Theory. As Dill (1958) points out, static environments create significantly less uncertainty than do dynamic ones and since uncertainty is a threat to an organisation's effectiveness, management will try to minimise it. As such, planners attempt to create 'normality' by ether resisting change, or attempting to use traditional linear project planning approaches. However, when the environment is unstable and rapidly changing, plans cannot be relied upon (Thompson 1967) and events can arise at faster rates than is practical to replan (Collyer \& Warren 2009). In such situations, different approaches are required (Collyer \& Warren 2009).

The rapid rate of change and the shortening of change cycles require a more dynamic and emergent approach (Collyer \& Warren 2009). This means a shift in focus towards more short-term strategies, which are implemented rapidly, sometimes within weeks, rather than adopting traditional long-term strategies, which now have no more than a 2-3 year time horizon (Van Der Merwe 2002).

\section{A new direction in project management}

The authors believe a new direction in project management is required, in particular, one that is aligned with the understanding of modern strategic management concepts as understood by 
top management; one that can be used in the implementation of strategy and can be adopted by project-based, product-based and service-based organisations alike.

This new direction does not involve the complete abandonment of existing mechanistic and normative project management ideals and concepts, but instead, requires a change of paradigm (Winter 2006). This would result in less reliance on outdated, linear and deterministic planning models, in favour of more emergent and adaptive methods reflecting other 'schools' of strategy.

Paradoxically, projects are meant to allow organisations to deal with complex and turbulent environments due to their temporary nature. Project-based approaches, therefore, need to be more organic in order to succeed in such environments. Existing models of project management, such as the PMBoK were not necessarily designed to cope with the complex multi-project context of modern organisations, nor do they focus on achieving strategic outcomes.

The use of program management structures appears to have merit. However, the implementation of an organisation's strategy is unlikely to consist of just one program. Multiple strategic goals are likely to require many programs, each delivering part of the organisation's overall strategic intent. Therefore, given the multi-program context, a program-portfolio approach is required to ensure consistency of action.

If portfolios of programs (rather than of projects) are required to cater for more dynamic arrangements, they could leverage Teece's (1997) concepts of dynamic capabilities and other recent strategic management thinking.

The new direction may also need to be situational or industry-specific, rather than being a standardised 'best way' to manage projects, programs and portfolios.

One thing that seems clear is that we may have reached the limits of project management. Two leading project management organisations, APMG and PMI, have commissioned major studies and conclude that project management tools have reached maturity (Sargeant 2010) but their value cannot be conclusively demonstrated (Thomas \& Mullaly 2008). The evidence is now very clear that projects cannot succeed without top management support (Young \& Jordan 2008) but the concepts underpinning project management and mainstream program and portfolio management have been rejected by top managers. If mechanistic assumptions continue to dominate these disciplines, they surely are headed down the path of rejection and are destined to mimic the fall of strategic planning documented by Mintzberg (1994).

However, there are promising new developments. Portfolio management already has the interest of top managers even if the underpinning concepts may be flawed. Project management is starting to explore complexity and is embracing the related concepts around emergence. Program management is often focused on strategic outcomes and the guidelines may only need to be revised to better reflect the emergent nature of strategy.

It is unclear where these developments are headed and Figure 4 is proposed as a schematic way to understand the situation. The double-S curve is often used to describe the evolution of technology and may describe the current developments in project management. Curve 1 represents the maturation of project management and the diminishing returns from additional effort. Curve 2 starts with a period of ambiguity, dilemma and discontinuity and may represent the tentative developments currently being made in program and portfolio 
management. Many attempts are being made to explain and embed the new developments in the mechanistic paradigms that underpin project management. If the issues are resolved in a manner that gains top management support, then the way is open for further development and possibly the birth of a new discipline.

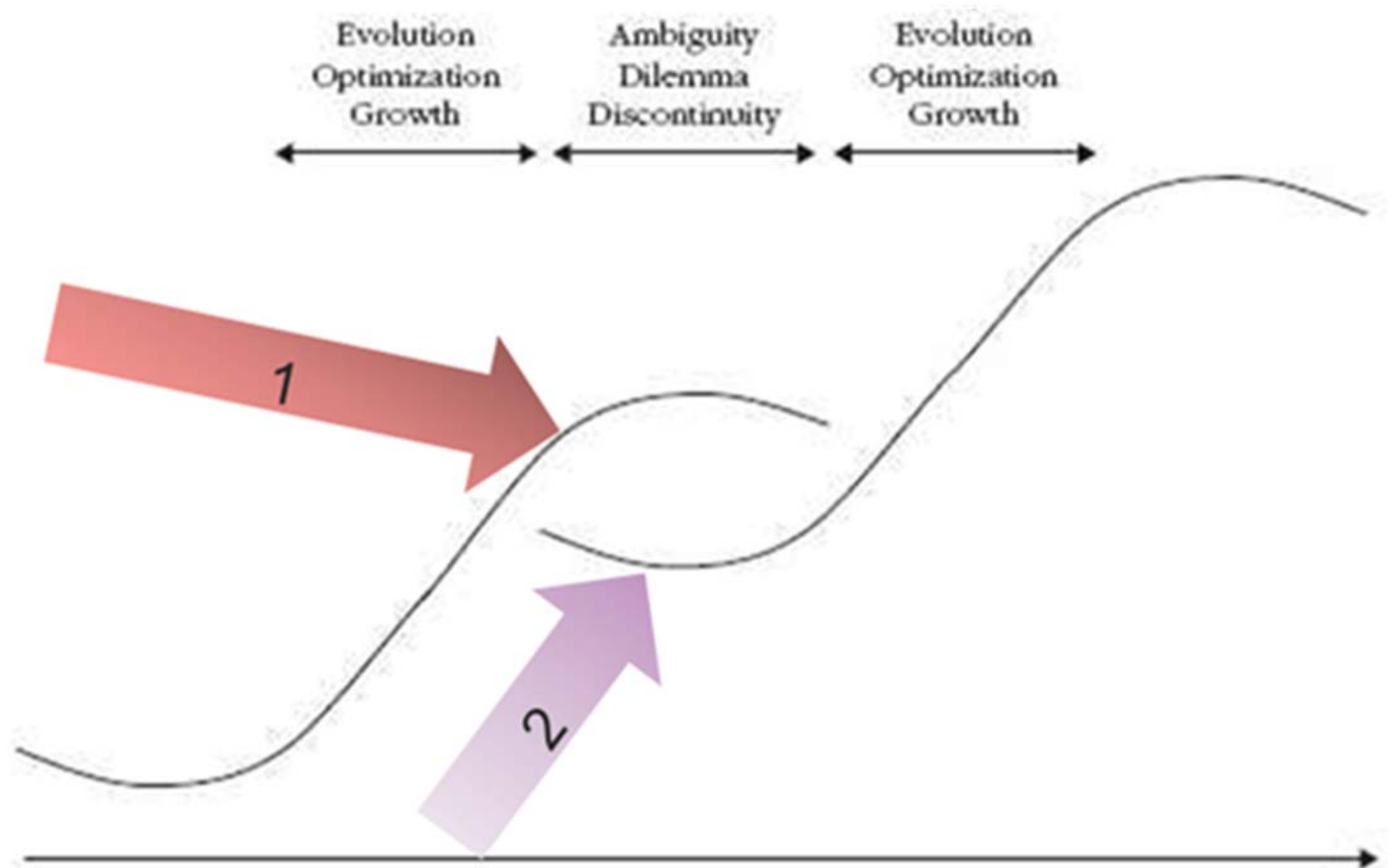

Figure 4. The maturing of project management (1) and the birth of a new discipline (2)?

This paper suggests a focus on the implementation of strategy and the realisation of strategic outcomes has the potential to open the way forward. However, it remains to be seen whether the profession will make this transition. Evidence suggests some who thrived under the old paradigms may not have the capacity to thrive in the more ambiguous, dynamic strategic business context (Partington, Pellegrinelli \& Young 2005) and there is considerable inertia in updating the bodies of knowledge (Morris, et al., 2006; Morris, Jamieson \& Shepherd 2006).

\section{Conclusion}

This conceptual paper has examined the existing state of the project, program and project portfolio management literature and has highlighted the divergent views of strategy that exist between project managers and top managers. Current project management concepts were shown to be based on approaches to planning that top managers had rejected after 30 years of unsuccessful experience with strategic planning. The project management literature was also found to be isolated from the mainstream management disciplines, unaware of developments in the strategic management literature and not sufficiently focused on an increasingly dynamic environment.

The question was asked whether project management was destined to follow the fate of strategic planning. It was suggested that project, program and portfolio management were unlikely to succeed in the long term if they could not engage the support of top managers. Persistently high project failure rates and recent developments at the board level calling for higher levels of governance support the view that we might have reached the limits of our current approaches and need to develop new ones. 
Alternatives to the traditional, linear, mechanistic approaches were explored by reviewing developments in the strategy literature. It was concluded that program and portfolio concepts had more in common with top management's concern with strategy and had more potential to bridge the two literatures as tools to support strategy implementation. However, it was suggested that before the two literatures could be bridged, the project management field would need to move towards embracing the delivery of strategy as the common ground to engage top managers and develop approaches that were consistent with how strategy emerges in turbulent environments.

\section{References}

Alexander, L.D. 1991, Strategy implementation: nature of the problem, in Hussey, D. (ed.), International Review of Strategic Management, John Wiley and Sons, New York, vol. 2, no. 1, 79-96.

Anderson, E.S. 1996, Warning: activity planning is hazardous to your project's health! International Journal of Project Management, vol. 14, no. 2, 89-94.

Ansoff, H.I. 1965, Corporate Strategy, McGraw-Hill, New York.

Archer, N. \& Ghasemzadeh, F. 1999, An integrated framework for project portfolio selection, International Journal of Project Management, vol. 17, no. 4, 207-216.

Archer, N. \& Ghasemzadeh, F. 2004, Project portfolio selection and management, in Morris, P.W. \& Pinto, J.K. (eds), The Wiley Guide to Managing Projects, John Wiley \& Sons, Hoboken, NJ, 237-255.

Artto, K., Martinsuo, M., Dietrich, P. \& Kujala, J. 2008, Project strategy: strategy types and their contents in innovation projects, International Journal for Managing Projects in Business, vol. 1, no. 1, 49-70.

AS8016 2010, Corporate Governance of Project Involving IT Investments, Standards Association of Australia, Sydney.

Balogun, J. 2006, Managing change: steering a course between intended strategies and unanticipated outcomes, Long Range Planning, vol. 39, no. 1, 29-49.

Bart, C.K. 1993, Controlling new product R\&D projects, R\&D Management, vol. 23, 187-197.

Bossidy, L. \& Charan, R. 2002, Execution: The Discipline of Getting Things Done, Crown Business, New York. Burns, T. \& Stalker, G.M. 1961, Management of Innovation, Tavistock, London.

Carlopio, J. 2006, Managing change: steering a coruse between intended strategies and unanticipated outcomes, Long Range Planning, vol. 39, no. 1, 29-49.

Chaffee, E. 1985, Three models of strategy. Academy of Management Review, vol. 10, no. 1, 89-98.

Choo, K. 2005, The praxis of strategic management in contemporary organisations: what are the implications for research and teaching? Problems and Perspectives in Management, 104-115.

Cleland, D.I. 2004, Strategic management: the project linkages, in Morris, P.W. \& Pinto, J.K. (eds), The Wiley Guide to Managing Projects, John Wiley \& Sons, Hoboken, NJ, 206-222.

Cleland, D. \& Ireland, L. 2007, Project Management: Strategic Design and Implementation 5th ed., McGrawHill, New York.

Collyer, S. \& Warren, C.M.J. 2009, Project management approaches for dynamic environments, International Journal of Project Management, vol. 27, no. 4, 355-364.

Cooke-Davies, T., Crawford, L. \& Lechler, T. 2009, Project management systems: moving project management from an operational to a strategic discipline, Project Management Journal, vol. 40, no. 1, 110-123.

Cooper, R., Edgett, S. \& Kleinschmidt, E. 1999, New product portfolio management: practices and performance. Journal of Product Innovation Management, vol. 16, 333-351.

Coyne, K.P. \& Subramaniam, S. 1996, Bringing discipline to strategy, McKinsey Quarterly, no. 4.

Crawford, L. 2004, Senior Mangement Perceptions of Project Management Competence, Project Management Institute, Newtown Square, PA.

De Reyck, B., Grushka-Cockayne, Y., Lockett, M., et al. 2005, The impact of project portfolio managment on information technology projects, International Journal of Project Management, vol. 23, 524-537.

Dietrich, P. \& Lehtonen, P. 2005, Successful managment of strategic intentions through multiple projects reflections from empirical study, International Journal of Project Management, vol. 23, no. 5, 386-391.

Dill, W.R. 1958, Environment as an influence of managerial autonomy, Administrative Science Quarterly, 409443.

Dinsmore, P.C. \& Cooke-Davies, T.J. 2006, The Right Projects Done Right!, John Wiley and Sons, San Francisco.

Dye, L.D. \& Pennypacker, J.S. 2000, Project portfolio management and managing multiple projects: two sides of the same coin? Proceedings of the Project Management Institute Annual Seminars \& Symposium. Project Management Institute, Houston, Texas.

Elfring, T. \& Volberda, H.W. 1994, New Directions in Strategy: Beyond Fragmentation, Sage, London. 
Emery, F.E. \& Trist, E.L. 1963, The causal texture of organisational environments. Human Relations, 21-21.

Fiegener, M.K. 1990, Towards a descriptive theory of strategic control: a study of the nature and effects of the organizational controls applied to strategies and strategic planning, PhD dissertation, available from Proquest: http://repository.upenn.edu/dissertations/AAI9026554.

Foti, R. 2002, Priority decisions. PM Network, April, 24-29.

Garrity, J.T. 1963, Top management and computer profits, Harvard Business Review, vol. 41, no. 4, 6-12.

Ghemawat, P. 2002, Competitition and business strategy in historical perspective, The Business History Review, 37-74.

Gilbert, D., Hartman, E. \& Mauriel, J. \&. 1988, A Logic for Strategy, Ballinger, Cambridge.

Grinyer, P.H. \& Spender, J.C. 1979, Turnaround: The Fall and Rise of the Newton Chambers Group, Association Business Press, London.

Grundy, T. 1998, Strategy implementation and project management, International Journal of Project Management, vol. 16, 46-50.

HB280 2006, Case Studies - How Boards and Senior Management Have Governed ICT Projects to Succeed (or Fail), Standards Association of Australia, Sydney.

Henderson, B.D. 1979, Henderson on Corporate Strategy, Abt Books, Cambridge, MA.

Hofer, C. \& Schendel, D. 1978, Strategy Formulation: Analytical Concepts, West Publishing Company.

Hogarth, R.M. \& Makridakis, S. 1981, Forecasting and planning: an evaluation, Management Science, vol. 27 no. 2, 115-138.

International Project Management Association 2008, IPMA Competence Baseline Version 3.0., International Project Management Association.

Jamieson, A. \& Morris, P.W. 2004, Moving from corporate strategy to project strategy, in Morris, P.W. \& Pinto, J.K. (eds), The Wiley Guide to Managing Projects, John Wiley \& Sons, Hoboken, NJ, 177-205.

Kaplan, R.S. \& Norton, D.P. 2008, The Execution Premium: Linking Strategy to Operations for Competitive Advantage, Harvard Business Press, Boston, MA.

Karlof, B. 1987, Business Strategy in Practice, Wiley, New York.

Keichell, W. 2010, The Lords of Strategy, Harvard Business Press, Boston.

Kerzner, H. 1998, Project Management: A Systems Approach to Planning, Scheduling and Controlling, 6th ed., John Wiley \& Sons, New York.

Krebs, J. 2009, Agile Portfolio Management, Microsoft Press, Washington.

Kwak, Y. \& Anbari, F. 2009, Analysing project management research: perspectives from top management journals, International Journal of Project Management, vol. 27, no. 5, 435-446.

Lederer, A. \& Mendelow, A. 1988, Information systems planning: top management takes control, Business Horizons, 73-78.

Lorange, P. 1998, Strategy implementation: the new realities, Long Range Planning, vol. 31, no. 1, 18-20.

Lycett, A., Rassau, A. \& Danson, J. 2004, Programme management: a critical revie, International Journal of Project Management, vol. 22, 289-299.

Markowitz, H. 1952, Portfolio selection, Journal of Finance, vol. 7, no. 1, 77-91.

McFarlan, F.W. 1981, Portfolio approach to infomration systems, Harvard Business Review, vol. 59, no. 5, 142150.

Miller, J. 2002, A proven project portfolio managment process, Proceedings of the Project Management Institute Annual Seminars \& Symposium, Project Management Institute, San Antonio, Texas.

Milosevic, D.Z. \& Srivannaboon, S. 2006, A theoretical framework for aligning project managment with business strategy, PMI Research Conference Proceedings, Project Management Institute, Montreal.

Milosevic, D.Z., Martinelli, R. \& Wadell, J.M. 2007, Program Management for Improved Business Results, John Wiley \& Sons, Hoboken, NJ.

Mintzberg, H. 1993, The pitfalls of strategic planning, Californian Management Review, vol. 36, no. 1, 32-45.

Mintzberg, H. 1994, The Rise and Fall of Strategic Planning, The Free Press, New York.

Mintzberg, H. \& Waters, J. 1985, Of strategies deliberate and emergent, Strategic Management Journal, 257272.

Mintzberg, H., Ahlstrand, B. \& Lampel, J. 2005, Strategy Safari: A Guided Tour Through the Wilds of Strategic Management, Free Press, New York.

Morris, P. 1994, The Management of Projects, Thomas Telford Services Ltd., London.

Morris, P. \& Jamieson, A. 2004, Translating Corporate Strategy into Project Strategy: Realising Corporate Strategy through Project Management, Project Management Institute, Newton Square.

Nasi, J. (ed.) 1995, Understanding Stakeholder Thinking, LSR Julkaisut Oy, Helsinki.

Office of Government Commerce 2007, Managing Successful Programmes, The Stationery Office, London.

Office of Government Commerce 2009, Portfolio Management Guide (Final Public Consultation Draft), The Stationery Office, London.

Okumus, F. 2003, A framework to implement strategies in organisations, Management Decision, vol. 41, no. 9, 871-882. 
Pelligrenelli, S. \& Bowman, C. 1994, Implementing strategy through projects, Long Range Planning, vol. 27 no. 4, 125-132.

Pelligrinelli, S. 1997, Programme management: organising project-based change, International Journal of Project Management, vol. 41, 141-149.

Pelligrinelli, S. 2008, Thinking and Acting as a Great Programme Manager, Palgrave MacMillan, Basingstoke.

Pelligrinelli, S., Partington, D., Hemingway, C. et al. 2007, The importance of context in programme management: an emprical review of programme practices, International Journal of Project Management, vol. 25, no. 1, 41-55.

Pinto, J.K., Clelend, D.I. \& Slevin, D.P. (eds) 2003, The Frontiers of Project Management Research, Project Management Institute, Newton Square, PA.

Porter, M.E. 1980, Corporate Strategy: Techniques for Analysing Industries and Competitors, Free Press, New York.

Porter, M. 1996 What is strategy?, Harvard Business Review, November-December, 61-78.

Prahalad, C.K. \& Hamel, G. 1994, Strategy as a field of study: why search for a new paradigm?, Strategic Management Journal, vol. 15, 5-16.

Project Management Institute 2008, A Guide to the Project Management Body of Knowledge, 4th ed., Project Management Institute, Newtown Square.

Quinn, J.B. 1978, Strategies for change: logical incrementalism, Sloan Management Review, Fall, 7-21.

Reiss, G., Anthony, M., Leigh, G., et al. 2006, Gower Handbook of Programme Management, Gower Publishing, Aldershot.

Rittel, H.W. \& Webber, M.M. 1973, Dilemmas in a general theory of planning, Policy Sciences, vol. 4, no. 2, 155-169.

Rockart, J. \& Crescenzi 1984, Engaging top management in information technology, Sloan Management Review.

Sargeant, R. 2010, Creating Value in Project Management Using PRINCE2, Queensland University of Technology, Brisbane.

Sauer, C. \& Reich, B. 2009, Rethinking IT project management: evidence of a new mindset and its implications. International Journal of Project Management, vol. 27, 182-193.

Senge, P.M. 1990, The Fifth Discipline: The Art and Practice of the Learning Organisation, Doubleday, New York.

Shenhar, A.J. \& Dvir, D. 2004, How projects differ, and what to do about it, in Morris, P.W. \& Pinto, J.K. (eds), The Wiley Guide to Managing Projects, John Wiley \& Sons, New York.

Srivannaboon, S. \& Milosevic, D. 2006, A two-way influence between business strategy and project management, International Jounral of Project Management, vol. 24, no. 3, 493-505.

Stewart, R. 1963, Reality of Management, Heinneman, London.

Stretton, A. 1992, Australian competency standards, International Journal of Project Management, vol. 13, no. 2, 119-123.

Sull, D. 2005, Strategy as active waiting, Harvard Business Review, vol. 83, no. 9, 120-129.

Teece, D. J., Pisano, G., \& Shuen, A. (1997). Dynamic Capabilities and Strategic Management. Strategic Management Journal, 509-534.

Thiry, M. 2010, Program Management. Gower Publishing.

Thiry, M. \& Deguire, M. 2006, Recent developments in project-based organisations, Proceedings of IRNOP VII Project Research Conference, Publishing House of Electronics Industry, Beijing, 2-15.

Thomas, J. \& Mullaly, M. 2008, Researching the Value of Project Management, Project Management Institute, Newton Square, PA.

Thompson, J. 1967, Organisations in Action, McGraw-Hill, New York.

Van Der Merwe, A.P. 2002, Project managment and business development: integrating strategy, sdtructure, processes and projects, International Jounral of Project Management, vol. 20, 401-411.

Van Donk, D.P. \& Molloy, E. 2007, From organizing as projects to projects as organizations, International Journal of Project Management, vol. 26, 129-137.

Weick, K.E. 1995, Sensemaking in Organisations, Sage, Thousand Oaks, CA.

Whitty, J. \& Schulz, M. 2007, The impact of Puritan ideology on aspects of project management, International Journal of Project Management, vol. 25, no. 1, 10-20.

Williams, D. \& Parr, T. 2004, Enterprise Programme Management: Delivering Value, Palgrave Macmillan, Basingstoke, Hampshire.

Wilson, I. 1994, Strategic planning isn’t dead — it changed, Long Range Planning, vol. 27, no. 4, 12-24.

Winter, M., Smith, C., Morris, P. \& Cicmil, S. 2006, Directions for future research in project management: the main findings of a UK government-funded research network, International Journal of Project Management, vol. 24, no. 8, 638-649.

Wright, P., Pringle, C. \& Kroll, M. 1992, Strategic Management Text and Cases, Allyn and Bacon, Needham Heights. 
Young, M. (2008). Projected Problems. Management Today.

Young, M., Owen, J., \& Connor, J. (2010). Whole of enterprise portfolio management: an integrated approach to managing projects as a social system. Proceedings of the 1st Asia Pacific Research forum on Project Management. Melbourne: Monash University.

Young, R., \& Jordan, E. (2008). Top management support: mantra or necessity? International Journal of Project Management, 26(7), 713-725.

Young, R., \& Jordan, E. (2010). Engaging top managers in the execution of strategy through projects. European Institute for Advanced Studies in Management. Valencia, Spain.

Young, R., Young, M., Jordan, E., \& O'Connor, P. (2012). Is strategy being implemented through projects? Contrary evidence from a leader in New Public Management. International Journal of Project Management.

\section{About the authors:}

Michael Young is an award-winning project and program manager with significant experience managing highrisk and complex projects in Australia and the Asia-Pacific across many industry sectors including: IT, transport and logistics, education and training, government and not-for-profit. Michael is a Certified Practicing Project Director, Fellow of the Australian Institute of Project Management (AIPM), is an AIPM-endorsed assessor, certified Gateway Review team member and is currently leading the development of the Australian National Competency Standards for project portfolio management. He is a former national board member of AIPM, and is completing his $\mathrm{PhD}$. Michael currently chairs the AIPM Standards Committee, the AIPM Knowledge and Research Council and is also a member of the AIPM Professional Development Council and the National Project Reference Group for the redevelopment of vocational project management qualifications in Australia and is the Australian delegate to the ICB 4 consensus project. Michael's research interests include project management competencies, organisational project delivery capabilities, strategy implementation and project portfolio management.

Email: info@transformed.com.au

Dr Raymond Young is a fellow of the Chartered Secretaries Australia, an assistant professor at the University of Canberra and an adjunct at the University of Sydney. Prior to joining academia he was a CIO in Fujitsu Australia and a management consultant with Deloitte. His research in project governance focuses on how the board and senior management influence projects to succeed. His research has been published by Standards Australia and he is a major contributor to Australian and International Standards on the governance of IT and projects enabled by IT (AS8016, ISO38500). 